\title{
STATUS MUTU AIR SUNGAI AYUNG BERDASARKAN DATA PEMANATUAN KUALITAS AIR TAHUN 2014-2018
}

\author{
I Made Sara Wijana*, Ni Made Ernawati, Abd Rahman As-syakur \\ Sumberdaya Alam dan Lingkungan Hidup Universitas Udayana \\ *Email: sarawijana@unud.ac.id
}

\begin{abstract}
It is very important to know the status of river water quality, in order to determine the direction of resource management which is decreasing in quality according to its allocation. Analysis of the status of the water quality of the Ayung River in Bali Province using secondary data in the form of data on illness results from 2014 to 2018. The number of parameters applied to the fire is 16 parameters with class II water quality standards referring to attachment XII of Bali Governor Regulation No. 16 of 2016 concerning Environmental Quality Standards and Environmental Damage Standard Criteria. The analysis used the Storetic Method (Decree of the Minister of Environment Number 115 of 2003). The results of the analysis show that the status of Ayung River water is at very good, good and moderate levels. The status of the Ayung River's air quality tends to decline from year to year and from upstream to downstream. Status determining parameters are: $\mathrm{BOD}_{5}$, phosphate, phenol, detergent and sulfide.
\end{abstract}

Key words: water quality status; ayung river; storet.

\section{PENDAHULUAN}

Sungai Ayung seperti sungai umumnya dikenal sebagai ekosistem terbuka (Open Ecosystem) yang akan mendapatkan limpasan (runoff) dari daerah sekitar sepanjang aliran sungai (Oddum, 1998). Limpasan ke dalam sungai dapat membawa berbagai jenis ion dan zat yang sebagian berasal dari atmosfeer, permukaan tanah, dan sebagian dari aktivitas manusia. Kadar ion dan zat lain yang tinggi dapat menyebabkan terjadinya pencemaran (de Vlaming et al., 2004; Izonfuo \& Bariweni, 2001). Sungai juga merupakan suatu ekositem air mengalir yang mempunyai peran penting dalam daur hidrologi dan berfungsi sebagai daerah tangkapan air (catchment area) bagi daerah di sekitarnya, sehingga kondisi suatu sungai sangat dipengaruhi oleh karakteristik lingkungan disekitarnya.

Sungai Ayung adalah sungai terpanjang di Provinsi Bali yaitu mencapai 68,5 km dan luas daerah aliran sungai (DAS) 30.981 ha (Sudarma dan Widyantara, 2016). Sungai Ayung melintasi 4 (empat) wilayah kabupaten/kota yaitu Kabupaten Bangli, Kabupaten Gianyar, Kabupaten Badung dan bermuara di Kota Denpasar. Kondisi lingkungan sekitar aliran sungai Ayung sangat beragam, seperti di daerah hulu yaitu di Kecamatan Payangan dan Petang alirannya melewati daerah semak belukar, di Kecamatan Ubud dan Abiansemal melewati lahan kebun dan sawah, sedangkan daerah alirannya yang melewati Kota Denpasar umumnya merupakan daerah permukiman (Dinas Lingkungan Hidup Provinsi Bali, 2014). Pemanfaatan aliran sungai Ayung untuk berbagai kepentingan oleh berbagai sektor, yaitu untuk kebutuhan irigasi oleh sektor pertanian, sebagai air baku untuk diolah menjadi air minum oleh PDAM (sektor air bersih), air mineral dalam kemasan (AMDK) dan aliran permukaannya dimanfaatkan sebagai usaha jasa rekreasi wisata arung jeram (rafting) terutama di 
beberapa bagian sungai yang berarus deras oleh sektor pariwisata. Di samping ketiga pemanfaatan tersebut, aliran air Sungai Ayung juga dimanfaatkan oleh masyarakat terdekat untuk kebutuhan domestik seperti untuk mandi, cuci dan kakus serta juga untuk kepentingan kegiatan sosial religius, seperti upacara Melasti, Nganyut, dan kegiatan ritual keagamaan lainnya. Atas dasar potensi yang dimiliki DAS Ayung, baik dilihat dari potensi aliran airnya (debit) maupun potensi pemandangan (lenskap) pada aliran Sungai Ayung dan DAS Ayung dijumpai usaha wisata arung jeram (rafting) dan sarana akomodasi berupa hotel, villa, dan sejenisnya termasuk restoran, rumah makan dan bar. Sehingga air Sungai Ayung sangat fital bagi kehidupan masyarakat dan ekosistem di sepanjang DAS Ayung yang perlu dijaga kelestariannya.

Banyak DAS yang mengalami penurunan kualitas dengan indikasi meningkatnya luas lahan kritis, semakin seringnya banjir, kekeringan, tanah longsor dan pencemaran air yang merugikan kehidupan masyarakat dan lingkungan. Penurunan kualitas DAS ini disebabkan antara lain oleh beberapa hal seperti tekanan penduduk yang meningkat akibat dari pembangunan industri, pembangunan infrastruktur, dan berkembangnya pemukiman, dijadikannya sebagai tempat pembuangan limbah padat (sampah) dan limbah cair, rendahnya kapasitas institusi yang bertugas mencegah dan merehabilitasi kerusakan sumberdaya, kebijakan yang belum berpihak kepada pelestarian sumberdaya alam (SDA), koordinasi yang belum optimal antar stakeholder terkait, dan kesadaran serta partisipasi berbagai pihak termasuk sebagian masyarakat yang masih kurang dalam konteks pemanfaatan dan pelestarian SDA (Sudarma dan Widyantara, 2016). Banyaknya tekanan tersebut di atas diperkirakan menurunkan kualitas air yang diindikasikan oleh nilai/kadar dari parameter kualitas air yang melampaui baku mutu. Sejauh mana nilai/kadar dari parameter kualitas air yang melampaui baku mutu terhadap status mutu air perlu dilakukan analisis mutu air. Analisis status mutu air menggunakan metode Storet.

Pemerintah Provinsi Bali melalui Dinas Lingkungan Hidup Provinsi Bali telah melakukan pemantauan kualitas air Sungai Ayung mulai tahun 2014 sampai dengan tahun 2018. Analisis data tersebut sangat penting dilakukan, untuk mengetahui kecenderungan status mutu air Sungai Ayung dalam bentuk time series sebagai dasar dalam menentukan arah kebijakan pengelolaan. Analisis status mutu air yang hanya berdasarkan pada data yang terbatas, kurang dapat menggambarkan kondisi dilapangan. Kadar atau nilai dari parameter kualitas air sangat tergantung pada kondisi pengambilan sampel, sehingga kadar atau nilai parameter hanya mewakili saat itu. Analisa terhadap data time series yang tersedia akan lebih baik dan diperoleh gambaran yang mendekati kenyataan sesuai kondisi lapangan.

\section{METODOLOGI}

\subsection{Lokasi Penelitian}

Lokasi penelitian meliputi aliran Sungai Ayung. Panjang Sungai Ayung kurang lebih 68,5 km dengan luas wilayah DAS 30.981 Ha. Sungai Ayung berhulu di Kabupaten Buleleng, Bangli dan Badung serta berhilir di Kota Denpasar. Wilayah DAS ini berada di sembilan wilayah kecamatan dengan 59 desa administratif. Pengumpulan data dilakukan melalui uji laboratorium sampel air. Sampel air diambil pada titik sampling secara purposive sampling yang ditentukan untuk mewakili bagian hulu, tengah dan hilir. Jumlah titik sampling untuk seluruhnya adalah 6 titik sampling, yang terdiri atas 1 titik untuk bagian hulu, 2 (dua) titik untuk bagian tengah dan 3 (tiga) titik untuk bagian hilir. Adapun lokasi titik sampling seperti pada Tabel 1 dan Gambar 1. 
Tabel 1. Lokasi dan Koordinat Titik Sampling Air di Sungai Ayung pada pemantauan Kualitas Air 2014-2018.

\begin{tabular}{|c|c|c|c|c|}
\hline No & Bagian/Segmen & Nama Desa & Lintang & Bujur \\
\hline 1 & Hulu & $\begin{array}{l}\text { Desa Buahan Kelod, Kec. Payangan, } \\
\text { Kab. Gianyar }\end{array}$ & $80 \quad 24,45,68$ & $115^{\circ} 14^{\prime} 25.37^{\prime \prime}$ \\
\hline 2 & Tengah 1 & $\begin{array}{l}\text { Dam Mambal, Kec. Abiansemal, } \\
\text { Kab. Badung }\end{array}$ & $8^{\circ} 3^{\prime}$ '46,57" & $115^{\circ} 13^{\prime} 00.87^{\prime \prime}$ \\
\hline 3 & Tengah 2 & $\begin{array}{l}\text { Dam Peraupan, Ds. Peguyangan } \\
\text { Kaja, Kec. Abiansemal, Kab. } \\
\text { Badung }\end{array}$ & $8^{\circ}$ 34' 56,13 " & $115^{\circ} 13^{\prime} 26.02^{\prime \prime}$ \\
\hline 4 & Hilir 1 & $\begin{array}{l}\text { Dam Oongan, Desa Tonja, Kec. } \\
\text { Denpasar Utara, Kota Denpasar }\end{array}$ & $8^{\circ} \quad 37^{\prime} 58,17^{\prime \prime}$ & $115^{\circ} 14^{\prime} 00.64^{\prime \prime}$ \\
\hline 5 & Hilir 2 & $\begin{array}{l}\text { Jembatan Jl. Gatsu Timur, Kel. } \\
\text { Penatih, Kec. Denpasar Utara, Kota } \\
\text { Denpasar }\end{array}$ & $8^{\circ} 38^{\prime} 09,56^{\prime \prime}$ & $115^{\circ} 14^{\prime} 21.73^{\prime \prime}$ \\
\hline 6 & Hilir 3 & $\begin{array}{l}\text { Jembatan Jl. By Pass Ngurah Rai } \\
\text { Tohpati, Kel. Kesiman Petilan, Kec. } \\
\text { Denpasar Timur, Kota Denpasar }\end{array}$ & $8^{\circ} 39^{\prime} 11,92^{\prime \prime}$ & $115^{\mathrm{O}} 15^{\prime} 13.82^{\prime \prime}$ \\
\hline
\end{tabular}

Sumber: Dinas Lingkungan Hidup Provinsi Bali, 2014-2018 


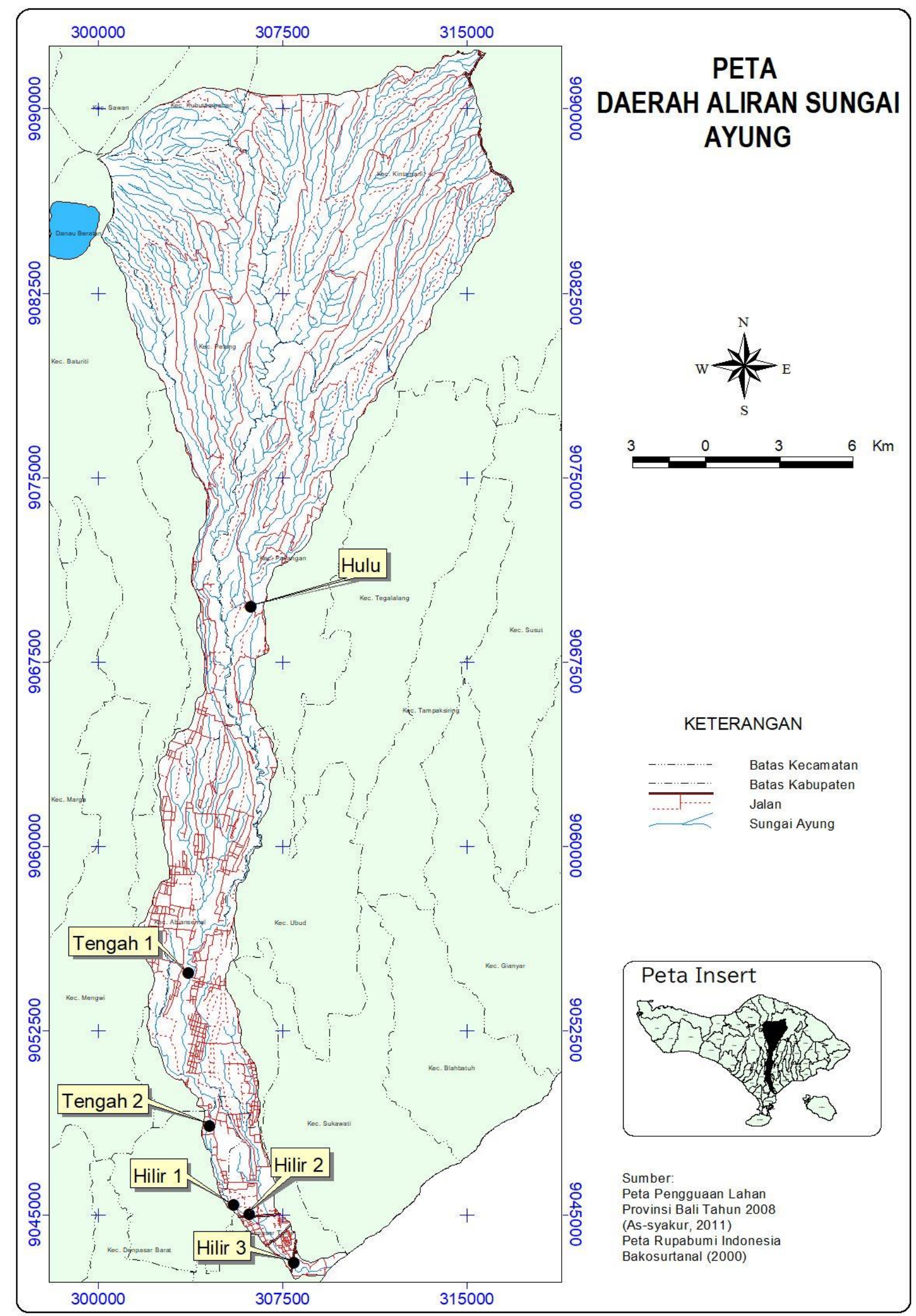

Gambar 1.

Peta Lokasi Sampling 
2.2. Waktu dan jumlah sampel, parameter, metode uji dan metode analisis data

Sampling dilakukan sebanyak 6 (enam) kali dalam setahun yaitu pada bulan April, Mei, Juli, September dan Oktober, sehingga jumlah sampel adalah sebanyak 36 sampel dalam setahun. Parameter yang di uji terdiri dari 2 (dua) parameter fisika, yaitu TSS dan TDS, dua belas (12) parameter kimia meliputi: BOD, $\mathrm{COD}$, Nitrit $\left(\mathrm{NO}_{2}\right)$, Nitrat $\left(\mathrm{NO}_{3}\right)$, Ammonia $\left(\mathrm{NH}_{3}\right)$, Klorin Bebas, Phospat $\left(\mathrm{PO}_{4}\right)$, Fenol, Minyak Lemak, Deterjen, Sianida, Sulifida dan 2 (dua) parameter biologi yaitu fecal colli dan total coliform. Metode uji terhadap parameter disajikan pada Tabel 2.

Tabel 2 Parameter dan metode pengujian

\begin{tabular}{|l|l|l|}
\hline \multicolumn{1}{|c|}{ No } & \multicolumn{1}{|c|}{ Parameter } & \multicolumn{1}{c|}{ Metode Pengujian } \\
\hline 1. & Total Diluted Solids $($ TDS) & gravimetri \\
\hline 2. & Total Suspended Solids $(\mathrm{TSS})$ & gravimetri \\
\hline 3. & BOD & titrimetri \\
\hline 4. & COD & titrimetri \\
\hline 5. & Ntrit $(\mathrm{NO} 2)$ & spektrofotometri \\
\hline 6. & Nitrat $\left(\mathrm{NO}_{3}\right)$ & spektrofotometri \\
\hline 7. & Amoniak $\left(\mathrm{NH}_{3}\right)$ & spektrofotometri \\
\hline 8. & Khlorin bebas & spektrofotometri \\
\hline 9. & Phosfat $(\mathrm{PO} 4)$ & spektrofotometri \\
\hline 10. & Fenol & spektrofotometri \\
\hline 11. & Minyak dan lemak & spektrofotometri \\
\hline 12. & Deterjen $(\mathrm{MBAS})$ & spektrofotometri \\
\hline 13. & Sianida $(\mathrm{CN})$ & spektrofotometri \\
\hline 14. & Sulfida $\left(\mathrm{S}^{2-}\right)$ & spektrofotometri \\
\hline 15. & Fecal coli & Metode Most Portable Number (MPN) \\
\hline 16. & Total coliform & Metode Most Portable Number (MPN) \\
\hline
\end{tabular}

Analisis data dengan motode Storet (storage and retrieval). Secara prinsip metode Storet adalah membandingkan antara data parameter kualitas air dengan baku mutu. Pada penelitian ini, baku mutu yang digunakan sebagai pembanding adalah baku mutu air Kelas II (Lampiran XII, Peraturan
Gubernur Bali No. 16 tahun 2016 tentang Baku Mutu Lingkungan Hidup dan Kriteria Baku Kerusakan Lingkungan Hidup). Data parameter kualitas air yang memenuhi baku mutu diberi skor 0 (nol) dan pemberian skor untuk parameter yang tidak memenuhi baku mutu dengan ketentuan seperti pada Tabel 3.

Tabel 3. Penentuan Skor Nilai Storet

\begin{tabular}{|l|l|c|c|c|}
\hline \multirow{2}{*}{ Jumlah contoh $^{1)}$} & \multicolumn{1}{|c|}{ Nilai } & \multicolumn{3}{c|}{ Parameter } \\
\cline { 2 - 5 } & & Fisika & Kimia & Biologi \\
\hline$<10$ & Maksismum & -1 & -2 & -3 \\
\cline { 2 - 5 } & Minimum & -1 & -2 & -3 \\
\cline { 2 - 5 } & Rata-rata & -3 & -6 & -9 \\
\hline \multirow{2}{*}{$\geq 10$} & Maksismum & -2 & -4 & -6 \\
\cline { 2 - 5 } & Minimum & -2 & -4 & -6 \\
\cline { 2 - 5 } & Rata-rata & -6 & -12 & -18 \\
\hline
\end{tabular}

Sumber: Canter (1977)

Keterangan: ${ }^{1}$ ) Jumlah paremeter yang dianalisis 
Penentuan status mutu air dilakukan dengan menggunakan system nilai dari (United State Enviromental Protection Agency) dengan mengklasifikasikan mutu air dalam empat klas, yaitu : 1) Kelas A (baik sekali), skor $=0$, memenuhi baku mutu; 2) Kelas B (baik), skor $=-1 \mathrm{~s} / \mathrm{d}-10$, cemar ringan; 3) Kelas C (sedang), skor $=-11 \mathrm{~s} / \mathrm{d}$ 30; dan 4) Kelas D (buruk), skor $\geq-31$, Cemar berat (KLH, 2003).

\section{HASIL DAN PEMBAHASAN}

Status mutu air Sungai Ayung pada lima tahun pengamatan berada pada status sedang sampai baik sekali dengan nilai Storet berkisar antara $0 \mathrm{~s} / \mathrm{d}-22$. Nilai Storet pada setiap titik sampling pertahun disajikan pada Tabel 4.

Tabel 4. Nilai Storet dan Status mutu air per lokasi per tahun

\begin{tabular}{|c|c|c|c|c|}
\hline Segmen & $\begin{array}{l}\text { Nama tempat } \\
\text { dan koordinat } \\
\text { titik sampling }\end{array}$ & Tahun & Nilai Storet & Status mutu air \\
\hline \multirow[t]{5}{*}{ Hulu } & \multirow{5}{*}{$\begin{array}{c}\text { Buahan (S 80 } \\
24^{\prime} 45,68^{\prime \prime} ; \\
\text { E115 } 15^{\circ} 4^{\prime} \\
\left.25.37^{\prime \prime}\right)\end{array}$} & 2014 & 0 & Baik sekali \\
\hline & & 2015 & 0 & Baik sekali \\
\hline & & 2016 & 0 & Baik sekali \\
\hline & & 2017 & -8 & Baik \\
\hline & & 2018 & -8 & Baik \\
\hline \multirow[t]{5}{*}{ Tengah 1} & \multirow{5}{*}{$\begin{array}{l}\text { Mambal (S } 8^{\circ} \\
32^{\prime} 46,57^{\prime \prime} ; \text { E } \\
115^{\circ} 13^{\prime} \\
\left.00.87^{\prime \prime}\right)\end{array}$} & 2014 & 0 & Baik sekali \\
\hline & & 2015 & 0 & Baik sekali \\
\hline & & 2016 & 0 & Baik sekali \\
\hline & & 2017 & -16 & Baik \\
\hline & & 2018 & -16 & Baik \\
\hline \multirow[t]{5}{*}{ Tengah 2} & \multirow{5}{*}{$\begin{array}{l}\text { Praupan } \\
8^{\circ} 34^{\prime} 56,13 " ; \\
115^{\circ} 13^{\prime} 26.02^{\prime \prime}\end{array}$} & 2014 & -2 & Baik \\
\hline & & 2015 & -3 & Baik \\
\hline & & 2016 & -4 & Baik \\
\hline & & 2017 & -22 & Sedang \\
\hline & & 2018 & -20 & Sedang \\
\hline \multirow[t]{5}{*}{ Hilir 1} & \multirow{5}{*}{$\begin{array}{l}\text { Oongan } \\
8^{\mathrm{O}} 37^{\prime} 58,17^{\prime \prime} \\
115^{\mathrm{O}} 14^{\prime} 00.64^{\prime \prime}\end{array}$} & 2014 & -4 & Baik \\
\hline & & 2015 & -13 & Sedang \\
\hline & & 2016 & -22 & Sedang \\
\hline & & 2017 & -22 & Sedang \\
\hline & & 2018 & -20 & Sedang \\
\hline \multirow[t]{5}{*}{ Hilir 2} & \multirow{5}{*}{$\begin{array}{l}\text { Gatsu } \\
8^{\mathrm{O}} 38^{\prime} \text {, 09,56"; } \\
115^{\mathrm{O}} 14^{\prime} 21.73^{\prime \prime}\end{array}$} & 2014 & -4 & Baik \\
\hline & & 2015 & -11 & Sedang \\
\hline & & 2016 & -22 & Sedang \\
\hline & & 2017 & -14 & Sedang \\
\hline & & 2018 & -20 & Sedang \\
\hline \multirow[t]{5}{*}{ Hilir 3} & \multirow{5}{*}{$\begin{array}{l}\text { IB Mantra }\left(8^{\mathrm{O}}\right. \\
39^{\prime} 11,92^{\prime \prime} ; 115^{\mathrm{O}} \\
15^{\prime}, 13.82^{\prime \prime}\end{array}$} & 2014 & -4 & Sedang \\
\hline & & 2015 & -13 & Sedang \\
\hline & & 2016 & -22 & Sedang \\
\hline & & 2017 & -22 & Sedang \\
\hline & & 2018 & -20 & Sedang \\
\hline
\end{tabular}

Tabel di atas menunjukkan bahwa terdapat kecenderungan penurunan status mutu air dari hulu ke hilir dan dari tahun ke tahun. Status mutu air di daerah hulu dan bagian tengah 1 pada tiga tahun pemantauan (tahun 2014, 2015 dan 2016) menunjukkan status baik sekali atau semua parameter memenuhi baku mutu. Pemantauan tahun 2017 dan 2018 dengan status baik, yang disebabkan oleh parameter $\mathrm{BOD}_{5}$ yang 
melampaui baku mutu. Status mutu air di bagian tengah 2 pada tiga tahun pemantauan ((tahun 2014, 2015 dan 2016) menunjukkan status baik dengan parameter $\mathrm{BOD}_{5}$ sebagai penentu status dan pada tahun 2017 dan 2018 dengan status sedang. Adapun parameter penentu status tersebut pada pemantauan tahun 2017 dan 2018 adalah : BOD $_{5}$, phosfat dan fenol. Status mutu air di bagian hilir 1 dan hilir 2 pada pemantauan tahun 2014 adalah baik dan pada tahun 2015, 2016, 2017 dan 2018 pada status sedang. Adapun parameter penentu status tersebut adalah $\mathrm{BOD}_{5}$, fenol, deterjen dan sulfida. Status mutu air di bagian hilir 3 mulai tahun 2014 sampai dengan 2018 adalah sedang/cemaran sedang. Gambaran parameter penentu status mutu air $\mathrm{BOD}_{5}$, fosfat, fenol, deterjen dan sulfide disajikan pada Gambar 2, Gambar 3, dan Gambar 4.

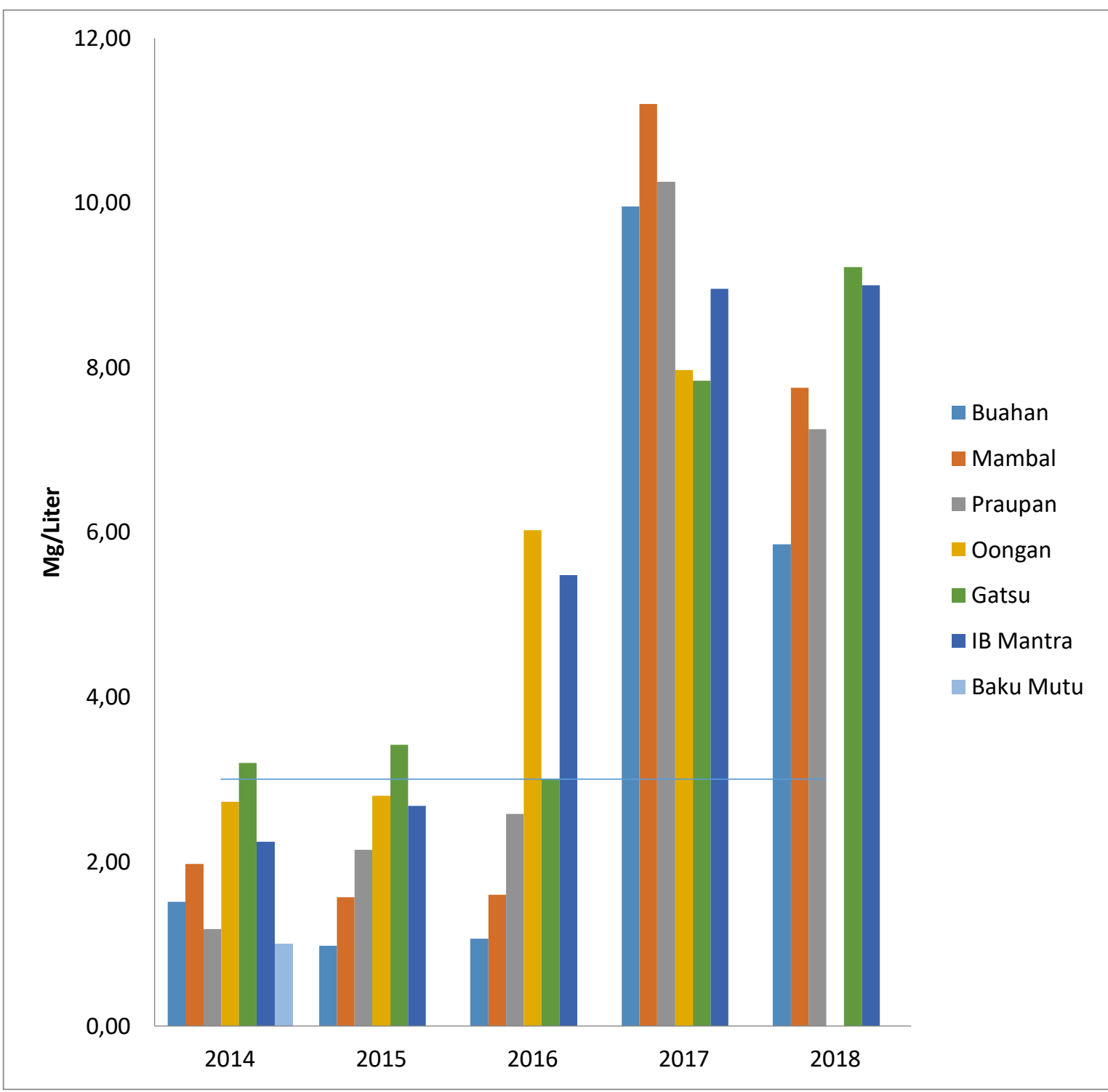

Gambar 2.

Grafik $\mathrm{BOD}_{5}$ Perlokasi untuk Setiap Tahun

Gambar $2 \mathrm{di}$ atas menunjukkan mutu. Hal ini disebabkan run of bahan bahwa nilai $\mathrm{BOD}_{5}$ ke arah hilir semakin organik di daerah hulu bersumber dari meningkat dan nilai $\mathrm{BOD}_{5}$ di daerah hilir kegiatan alami seperti dari serasah tumbuhmulai tahun 2015 semuanya melampaui baku tumbuhan dan dari kegiatan domestik dalam 
jumlah yang terbatas sehingga masih dapat di purifikasi secara alami (Self purification) atau disebabkan oleh kemampuan purifikasi bahan organik di daerah hulu lebih tinggi disbanding dengan di derah hilir. Tingginya kemampuan purifikasi bahan organic di daerah hulu disebabkan oleh tingginya input oksigen dari udara ke dalam air. Tingginya infut oksigen dari udara ke dalam air di daerah hulu disebabkan oleh turbulensi aliran sungai yang dipengaruhi oleh kondisi dasar, kedalaman dan kemiringan. Input bahan organik di daerah hilir dapat dipastikan lebih banyak yang disebabkan oleh semakin padatnya permukiman dan aktivitas di sekitar DAS, disamping secara umum daerah hilir Sungai Ayung airnya lebih tenang, lebih dalam dan aliran anak sungai yang masuk lebih sedikit, sehingga bahan organik yang masuk semakin banyak dan infut oksigen semakin menurun sehingga bahan organik yang tersisa atau tidak terurai semakin banyak. Bahan organik yang tinggi akan meningkatkan kebutuhan oksigen oleh bakteri dalam dekomposisi bahan organik (Arbie dkk.,2015).

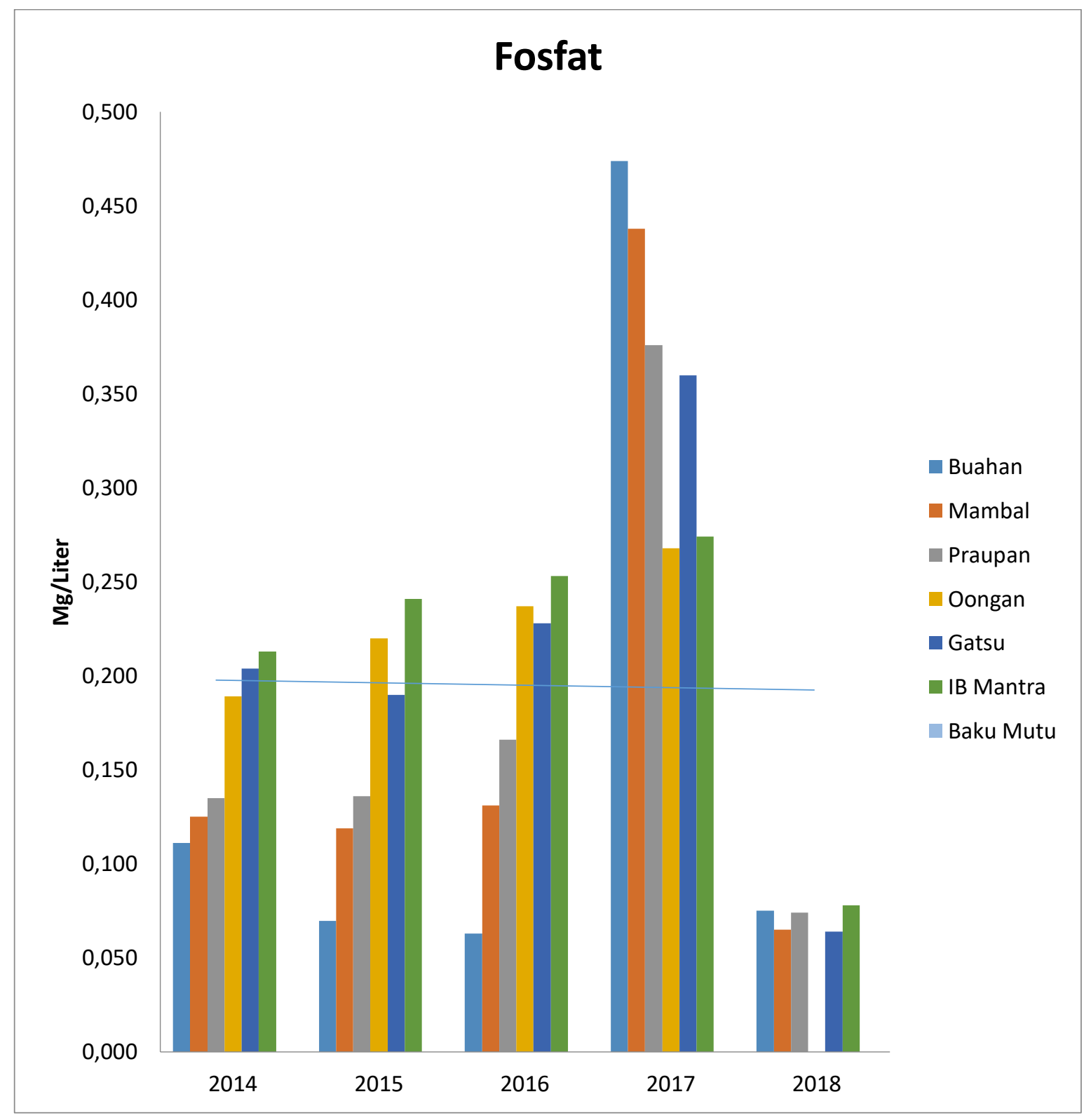

Gambar 3.

Grafik Kadar Fosfat Perlokasi untuk Setiap Tahun 
Fosfat $\left(\mathrm{PO}_{4}\right)^{-3}$ dapat ditemukan sebagai ion beebas dalam air dan sebagai garam di daratan yang digunakan dalam deterjen sebagai pelunak air. Fosfat bida dalam bentuk organik atau anorganik termasuk ortofosfat dan polifosfat (Atobatele and Olutona, 2013). Kadar fosfat memiliki kecenderungan meningkat dari daerah hulu ke daerah hilir dan meningkat sangat tajam pada pemantauan tahun 2017. Tingginya kadar fosfat pada tahun 2017 mulai dari hulu sampai hilir diperkirakan karena anomali cuaca, yaitu terjadi hujan sepanjang tahun. Fosfat yang berasal dari batuan, sisa pemupukan dan yang bersumber dari kegiatan antropogenik lainnya akan hanyut dan masuk ke badan-badan air termasuk aliran Sungai Ayung. Girija at all (2007) juga menemukan konsentrasi fosfat meningkat di Sungai Brahmaputra, India pada musim hujan.
Senyawa fenol memiliki daya tahan lama di lingkungan dan bersifat akumulatif yang bersifat toksik terhadap manusia dan hewan. Masuknya senyawa fenol ke lingkungan dihasilkan dari alam, kegiatan industry, domestik dan pertanian yang dihasilkan karena degradasi atau dekomposisi bahan organik alami yang ada dalam air, melalui pembuangan limbah industri atau dari kegiatan rumah tangga serta melalui limpasan dari lahan pertanian (Anku, W.W., M.A. Mamo, and P.P. Govender 2017). Senyawa fenol di dalam air memiliki kecenderungan mengalami transformasi yang bisa lebih berbaya dari pada senyawa aslinya. Ini terjadi kerena interkasinya secara fisik, kimi dan biologis atau factor mikroba di dalam air. Data kandar fenol selama 5 tahun pemantauan yang dilaksanakan tidak menunjukkan pola tertentu seperti ditunjukkan pada Gambar 4.

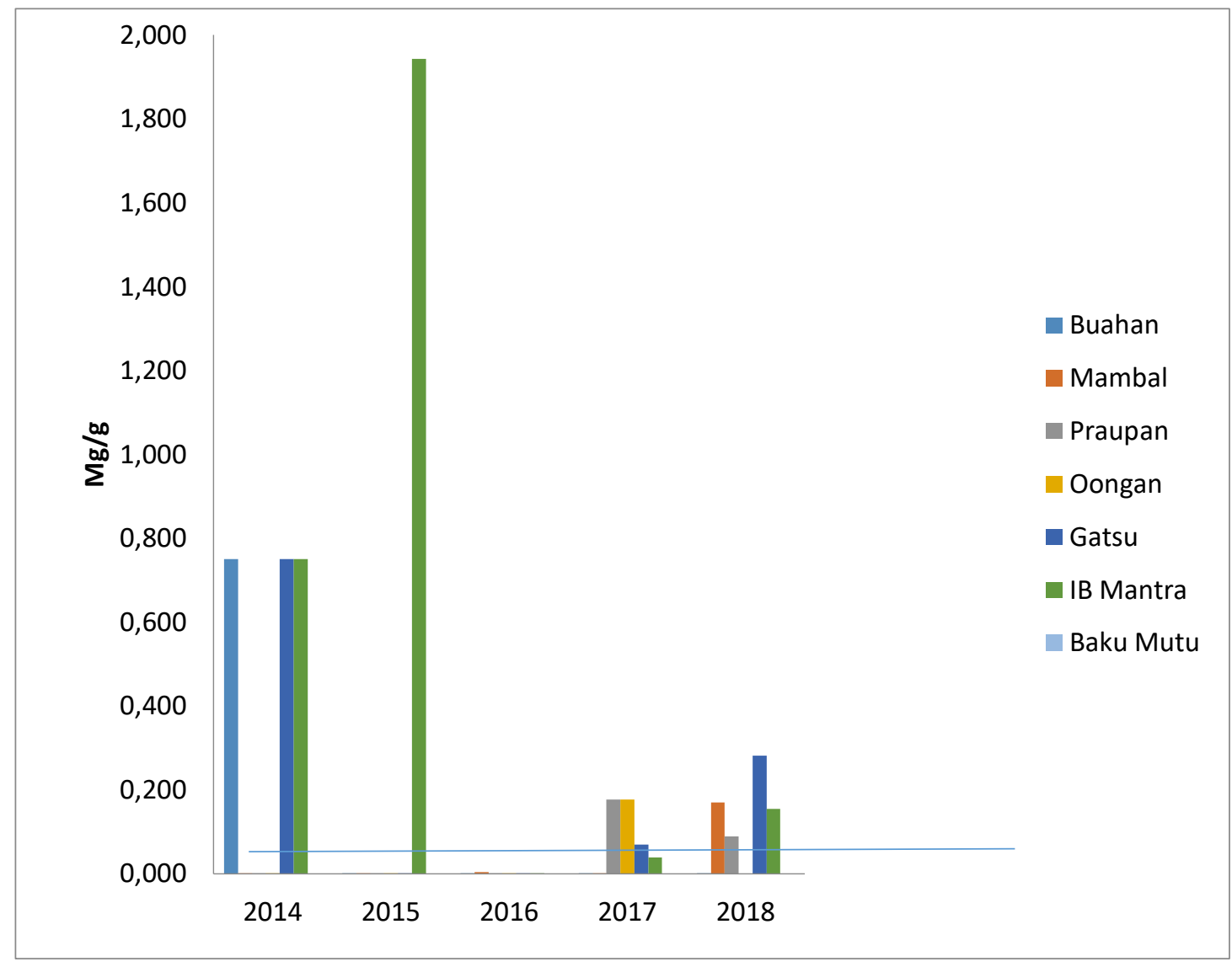

Gambar 4.

Grafik Kadar Fenol Perlokasi untuk Setiap Tahun 


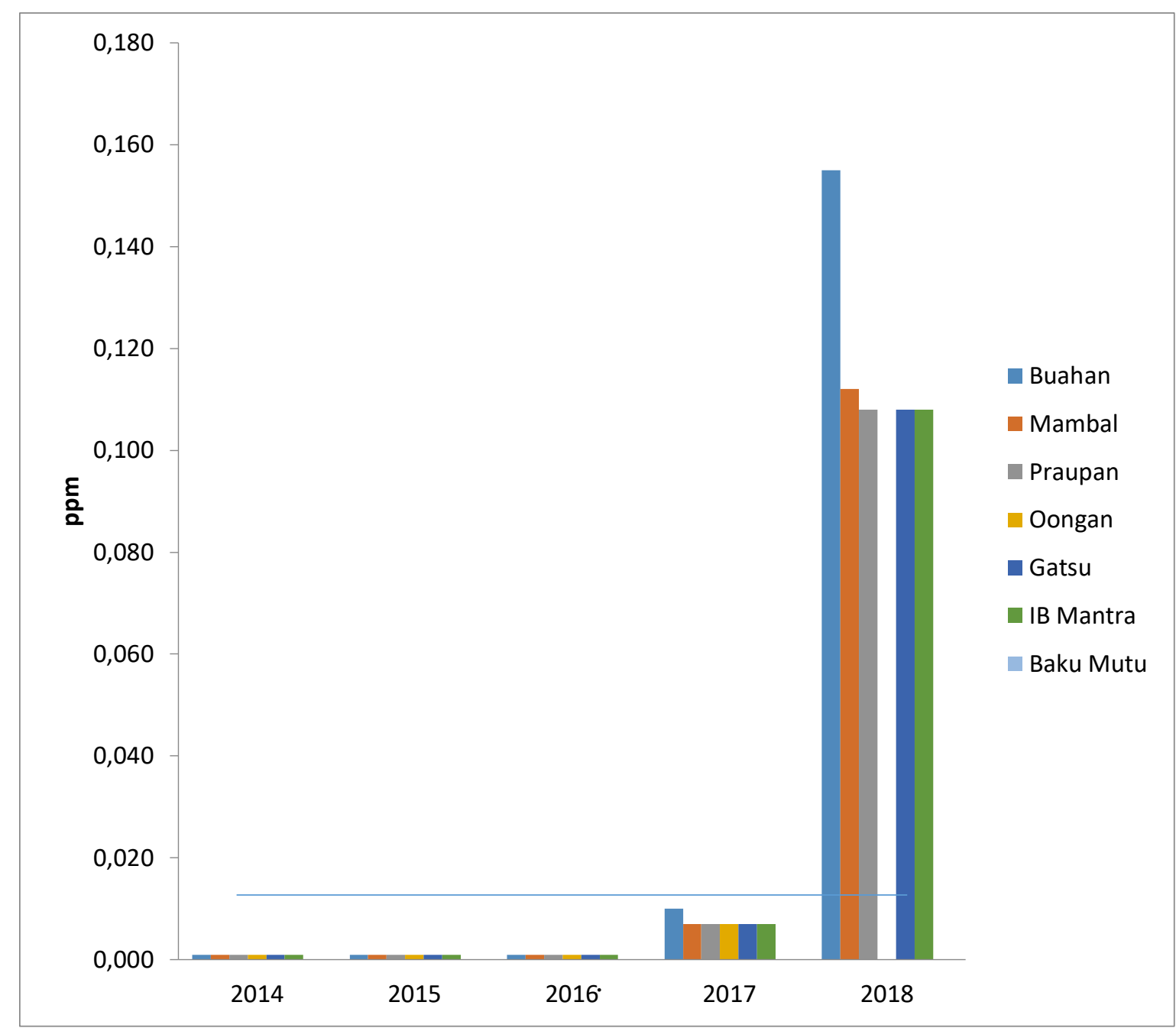

Gambar 5.

Grafik Kadar Sulfida Perlokasi untuk Setiap Tahun

Senyawa sulfide dalam perairan ditemukan dalam bentuk $\mathrm{H}_{2} \mathrm{~S}$ yang berbasu busuk dihasilkan dari proses degradasi senyawa yang mengandung sulfur oleh bakteri anaerob. Proses anaerob ini biasanya terjadi di perairan yang tidak bersirkulasi dan kurang kontak langsung dengan udara sehingga mengurangi kemampuan air untuk melarutkan oksigen. Kadar sulfide memiliki kecenderungan meningkat ke arah hilir dan paling tinggi untuk semua segmen pada tahun 2018. Ini menandakan bahwa ada infut bahan organic yang semakin tinggi dan oksigen yang semakin berkurang ke arah hilir. Hal ini berkaitan infut oksigen yang semakin berkurang yang diakibatkan oleh turbulensi air ke arah hilir semakin berkurang. Ketika oksigen terlarut tidak tersedia lagi maka penguraian bahan organik akan dilakukan oleh mikroorganisme anaerob yang mengeluarkan gas asam sulfida $\left(\mathrm{H}_{2} \mathrm{~S}\right)$ dan gas metana $\left(\mathrm{CH}_{4}\right)$ (Purnomo et al., 2013). Jika kandungan oksigen meningkat maka sulfur akan teroksidasi dalam bentuk ion seperti sulfat sehingga menurunkan pembentukan hidrogen sulfida. (Henny dan Nomosatryo, 2012).

\section{SIMPULAN}

Berdasarkan hasil pembahasan di atas, dapat disimpulkan hal-hal sebagai berikut:

1) Status mutu air Sungai Ayung berada pada status baik sekali, baik dan sedang

2) Status mutu air Sungai Ayung menunjukkan kecenderungan semakin 
menurun dari tahun ke tahun dan dari hulu ke hilir

3) Parameter penentu status mutu ari Sungai Ayung, yaitu :BOD 5 , fosfat, fenol, deterjen dan sulfide.

\section{DAFTAR PUSTAKA}

Atobatele, E.O. and Olutona, G.O. (2013). Spatioseasonal physico-chemistry of Aiba stream, Iwo, Nigeria. African Journal of Biotechnology, 12(14): 1630-1635.

Arbie, R.R., E.D. Nugraha., Sudarsono., 2015. Jurnal Teknik Lingkungan, Vol 4, No 3 hal 1-15. http://ejournals1.undip.ac.id/index.php/tlingkungan.

Girija, T.R., C. Mahanta., V. Chandramouli., 2007. Water Quality Assessement of an Untreated Effluent Impacted Urban Stream: The Bharalu Tributary of the Brahmaputra River, India. Environ Monit Asses (2007) 130:221-236.

Sofia E dan R. Riduan., 2017. Evaluasi dan Analisis Pola Sebaran Sisa Klor Bebas Pada Jaringan Distribusi IPA Sungai Lulut PDAM Bandar Masih. Jukung Jurnal Teknik Lingkungan, 3 (2): $10-24$.

Anku, W.W., M.A. Mamo, and P.P. Govender 2017. Phenolic Compounds in Water : Sources, Reactivity, Toxixity and Treatment Methods. Reviewed Chafter 17. http://dx.doi.org/10.5772/66927.

Purnomo, P.W., M. Nitisupardjo, Y. Purwandari, 2013. Hubungan Antara Total Bakteri Dengan Bahan Organik, NO3 dan H2S Pada Lokasi Sekitar Eceng Gondok dan Perairan Terbuka Di Rawa Pening. Journal of Management of Aquatic Resources. 2(3), pp. $74 \pm 84$.

Henny, C., S. Nomosatryo, 2012. Dinamika Sulfida Di Danau Maninjau: Implikasi Terhadap Pelepasan Fosfat
Di Lapisan Hipolimnion. Prosiding Seminar Nasional Limnologi VI Tahun 2012. Bogor, Indonesia.

Peraturan Gubernur Bali No. 16 tahun 2016 Tentang Baku Mutu Lingkungan Hidup Dan Kriteria Baku Kerusakan Lingkungan Hidup.

De Vlaming, V., C. Di Giorgio, S. Fong, M.D. L.A. Deanovic, de la Paz Carpio-Obeso, J.1. Miller. 2004. Irigation runoff insecticide pollutin of rivers in the Imperial Valley, California, USA. Enviromental Pollution, 132, 213-229.

Sudarma, I Made ; Widyantara, Wayan. 2016. Persepsi Masyarakat Terhadap Ekosistem Daaerah Aliran Sungai Ayung Menuju Sumberdaya air Berklanjutan. Bumi Lestari Journal of Enviromen. Vol 16 No.2. hal 78-91. 